\title{
Perlindungan Hukum Pada Korban Tindak Pidana Lingkungan Hidup Melalui Mediasi Penal Dalam Perspektif Pembaruan Hukum Pidana
}

Oleh :

Subaidah Ratna Juita, Doddy Kridasaksana' Ani Triwati

Fakultas Hukum, Universitas Semarang

ratna@yahoo.com,doddy_kridasaksana@gmail.com anitriwati@yahoo.com

\begin{abstract}
Abstrak
Dalam sistem peradilan pidana untuk mengupayakan adanya mediasi penal. dilatar belakangi pemikiran yang dikaitkan dengan ide-ide pembaruan hukum pidana (penal reform). Latar belakang dilakukannya pembaruan hukum pidana itu antara lain didasarkan pada ide perlindungan pada korban tindak pidana. Bagi korban dan calon korban pencemaran dan/atau perusakan lingkungan yang diperlukan adalah adanya perangkat hukum yang memberikan jaminan perlindungan. Adapun permasalahan dalam penelitian ini adalah berkaitan dengan aspek perlindungan hukum pada korban tindak pidana lingkungan hidup melalui alternatif penyelesaian perkara tindak pidana lingkungan hidup di luar pengadilan, yakni melalui mediasi penal dalam perspektif pembaruan hukum pidana. Metode penelitian yang digunakan dalam penelitian ini adalah yuridis normatif, yaitu dengan mengkaji atau menganalisis data sekunder yang berupa bahan-bahan hukum primer, dengan memahami hukum sebagai perangkat peraturan atau norma- norma positif di dalam sistem perundang-undangan yang mengatur mengenai korban tindak pidana lingkungan hidup. Hasil penelitian menunjukkan, bahwa perlunya alternatif penyelesaian perkara tindak pidana lingkungan hidup di luar pengadilan, sebagai wujud konkret perlindungan hukum pada korban tindak pidana lingkungan hidup. Hal ini berarti dalam perspektif pembaruan hukum pidana perlu dilakukan revisi yang berkaitan dengan perumusan Pasal 85 ayat (2) Undang-Undang No. 32 Tahun 2009 tentang Perlindungan dan Pengelolaan Lingkungan Hidup, yang seyogyanya juga dapat dijadikan sebagai dasar hukum bagi penyelesaian TPLH di luar pengadilan.
\end{abstract}

Kata Kunci : perlindungan hukum; tindak pidana lingkungan hidup; mediasi penal; pembaruan hukum pidana; 


\begin{abstract}
In the criminal justice system to seek penal mediation. based on thoughts associated with ideas of reform of penal law (penal reform). The background of the criminal law reform is based on the idea of protection for victims of crime. For the victims and potential victims of pollution and / or environmental damage required is the existence of a legal device that provides protection coverage. The problem in this research is related to the aspect of legal protection to the victim of environmental crime through alternative of environmental crime case settlement outside court, that is through penal mediation in perspective of criminal law renewal. The research method used in this study is normative juridical, that is by reviewing or analyzing secondary data in the form of main legal material, by understanding the law as a set of rules or norms positive in the legislation system that regulates the victims of environmental crime life. The results show that the need for alternative settlement of environmental crime cases outside the court, as a real form of legal protection for victims of environmental crime. This means that in the perspective of reform of the criminal law, it is necessary to revise the formulation of Article 85 paragraph (2) of Law no. 32 of 2009 on Environmental Protection and Management, which should also be the legal basis for the settlement of TPLH out of court.
\end{abstract}

Keywords:legal protection; environmental crime victim; penal mediation; and criminal law update;

\title{
PENDAHULUAN
}

Mediasi penal merupakan Alternatif penyelesaia perkara pidana di luar jalur penal. Dalam penyelesaian perkara pidana jika menempuh jalur penal biasanya selalu adanya penjatuhan pidana oleh hakim terhadap pelaku, hal ini secara filosofis kadang-kadang tidak memuaskan semua pihak, oleh karena itu perlu adanya pemikiran penyelesaian perkara pidana melalui jalur ADR (Alternative Dispute Resolution) dengan maksud agar dapat menyelesaikan konflik yang terjadi antara pelaku dengan korban.

Menurut Muladi, model konsensus yang dianggap menimbulkan konflik baru harus diganti dengan model asensus, karena dialog antara yang berselisih untuk menyelesaikan masalahnya, adalah langkah yang sangat positif. Dengan 
konsep ini muncul istilah ADR yang dalam hal-hal tertentu menurut Muladi lebih memenuhi tuntutan keadilan dan efesien. ADR ini merupakan bagian dari konsep restorative justice yang menempatkan peradilan pada posisi mediator. ${ }^{1}$

Mengkaji mengenai formulasi hukum pidana masa datang (ius constituendum) tidak bisa dilepaskan dari formulasi hukum pada saat sekarang (ius costitutum), karena untuk menyusun formulasi masa datang tetap harus melihat kondisi saat ini.

Dalam melakukan pembaruan hukum bisa dengan menata kembali hukum yang sudah ada atau membangun yang baru sama sekali. Jadi dalam hal ini berkaitan dengan "law reform" dan "law development" terutama berkaitan dengan pembaruan dan pembangunan sistem hukum pidana. Dapat dikatakan bahwa antara kebijakan pembangunan hukum pidana dan tujuan pembangunan nasional diperlukan pendekatan yang sinergis sehingga tetap terjaga kehidupan masyarakat dalam kesatuan negara berdasarkan Pancasila.

Dengan melihat kondisi penegakan hukum pidana terhadap perbuatan pencemaran dan/atau perusakan lingkungan hidup yang telah berlangsung selama ini, sudah seyogyanya mediasi penal dijadikan alternatif penyelesaian perkara tindak pidana lingkungan hidup di luar pengadilan.

Menjadikan mediasi penal sebagai alternatif penyelesaian perkara tindak pidana lingkungan hidup selain bermanfaat bagi lingkungan hidup, sejalan dengan perkembangan hukum dalam tataran global, sejalan pula dengan hukum yang hidup dan berkembang dalam tataran lokal, yakni masyarakat adat di Indonesia yang telah memiliki mekanisme penyelesaian perkara melalui perundingan atau permusyawarahan untuk mencapai kesepakatan.

Bertolak dari hal tersebut maka permasalahan dalam penelitian ini adalah bagaimanakah perlindungan hukum pada korban tindak pidana lingkungan hidup melalui mediasi penal dalam perspektif pembaruan hukum pidana?

\footnotetext{
${ }^{1}$ Muladi, Hak Asasi Manusia, Politik dan Sistem Peradilan Pidana, (Semarang: Badan Penerbit Universitas Diponegoro, 1997), halaman 67.
} 
Berdasarkan perumusan masalah di atas, penelitian ini bertujuan untuk mengetahui perlindungan hukum pada korban tindak pidana lingkungan hidup melalui mediasi penal dalam perspektif pembaruan hukum pidana. Sementara itu hasil penelitian ini diharapkan dapat memberikan kontribusi baik secara teoritis maupun secara praktis, yaitu:

1. Secara teoritis, hasil penelitian ini diharapkan dapat memberikan sumbangan pemikiran bagi ilmu pengetahuan, khususnya hukum pidana dalam kaitannya dengan perlindungan hukum pada korban tindak pidana lingkungan hidup melalui mediasi penal dalam perspektif pembaruan hukum pidana.

2. Secara praktis, hasil penelitian diharapkan dapat memberikan manfaat bagi aparat penegak hukum untuk memperluas wacana mengenai perlindungan hukum pada korban tindak pidana lingkungan hidup melalui mediasi penal dalam perspektif pembaruan hukum pidana. Bagi penentu kebijakan, penelitian ini diharapkan dapat memberikan masukan dalam menetapkan kebijakan mengenai penyelesaian perkara tindak pidana lingkungan hidup melalui mediasi penal dalam rangka memberikan perlindungan hukum pada korban tindak pidana lingkungan hidup.

\section{METODE PENELITIAN}

\section{a. Metode Pendekatan}

Penelitian mengenai perlindungan hukum pada korban tindak pidana lingkungan hidup melalui mediasi penal dalam perspektif pembaruan hukum pidana ini merupakan penelitian hukum normatif, yaitu penelitian yang menitikberatkan pada data sekunder.

\section{b. Spesifikasi Penelitian}

Bertitik tolak dari judul dan permasalahan yang mendasari penelitian ini, maka penelitian ini termasuk jenis penelitian deskriptif- analitis, yaitu menggambarkan peraturan perundang-undangan yang berlaku sebagai hukum positif dikaitkan dengan teori hukum dan praktek pelaksanaan hukum positif 
dalam masyarakat. Dengan demikian, dari penelitian ini dapat memberikan gambaran mengenai perlindungan hukum pada korban tindak pidana lingkungan hidup melalui mediasi penal dalam perspektif pembaruan hukum pidana.

\section{c. Metode Pengumpulan}

Berdasarkan pendekatan yang dipergunakan dalam penelitian ini, maka metode pengumpulan data yang dipergunakan adalah studi kepustakaan atau dokumen (library research). Studi kepustakaan dilakukan terhadap data sekunder, yaitu data yang bersumber dari penelitian kepustakaan, dan diperoleh tidak secara langsung dari sumber pertamanya, melainkan bersumber dari data-data yang sudah terdokumentasi dalam bentuk bahan-bahan hukum. Penelitian kepustakaan ini dimaksud untuk memperoleh data sekunder dengan mempelajari literaturliteratur, peraturan perundang-undangan, teori-teori, pendapat para sarjana dan hal-hal lain yang berkaitan dengan objek penelitian.

\section{d. Metode Analisis Data}

Analisis data dilakukan secara kualitatif kemudian diidentifikasi serta dilakukan kategorisasi. Analisis kualitatif yaitu metode analisis yang pada dasarnya menggunakan pemikiran logis, analisis dengan logika ${ }^{2}$. dengan induksi, deduksi, analogilinterpretasi, komparasi dan sejenis itu. ${ }^{3}$ Metode berpikir yang digunakan adalah metode deduktif yaitu dengan berdasarkan pada dasar pengetahuan yang bersifat umum untuk mengkaji persoalan-persoalan yang bersifat khusus. Dari hasil analisis tersebut kemudian akan ditarik kesimpulan sebagai jawaban atas permasalahan yang ada.

\section{HASIL DAN PEMBAHASAN}

Perkara yang timbul akibat terjadinya tindak pidana lingkungan hidup (TPLH) pada dasarnya adalah terjadinya benturan kepentingan antara pihak yang melakukan perbuatan perusakan dan/atau pencemaran lingkungan hidup (pelaku)

\footnotetext{
${ }^{2}$ Analisis kualitatif pada dasarnya mempergunakan pemikiran logis analitis (lihat M. Sommers, Logika, (Bandung,: Alumni, 1992), halaman 2, demikian pula Jujun S. Suriasumantri, Filsafat Ilmu-Sebuah Pengantar Populer, (Jakarta: Pustaka Sinar Harapan, 1996), halaman 43. 95.

${ }^{3}$ Tatang A. Amirin, Menyusun Rencana Penelitian, (Jakarta: CV. Rajawali, 1986 ), halaman
} 
dan pihak yang dirugikan akibat perbuatan pencemaran dan/atau perusakan lingkungan hidup (korban). Sesuai perundang-undangan yang berlaku, cara penyelesaian perkara TPLH adalah melalui proses di pengadilan.

Kendala penyelesaian perkara TPLH melalui proses pengadilan pada umumnya adalah menyangkut kesulitan pembuktian, karena pembuktian dalam TPLH sangat rumit dan membutuhkan biaya besar. Sehingga banyak perkara TPLH yang tidak dapat diselesaikan di pengadilan.

Dalam rangka memberikan perlindungan hukum pidana secara maksimal pada korban tindak pidana lingkungan hidup perlu dilakukan pembaruan hukum pidana. Perlindungan hukum pidana pada korban tindak pidana lingkungan hidup adalah melalui penegakan hukum lingkungan hidup dengan menggunakan sarana hukum pidana yang selama ini acapkali terkendala pada kesulitan pembuktian. Pembuktian perkara TPLH membutuhkan SDM dan teknologi yang tinggi, sehingga penyelesaian perkara tindak pidana lingkungan hidup menjadi rumit, mahal dan berlangsung lama. ${ }^{4}$

Kondisi tersebut secara substansial tidak sejalan dengan hakikat perlindungan lingkungan hidup, karena semakin lama proses penyelesaian perkara tindak pidana lingkungan hidup, maka kerusakan dan/atau pencemaran lingkungan hidup akan terus berlangsung, menjadi semakin parah, dan semakin kecil kemungkinan pemulihannya. Rumit, mahal dan lamanya penyelesaian perkara tindak pidana lingkungan hidup melalui pengadilan merupakan latar belakang pemikiran perlunya alternatif penyelesaian perkara tindak pidana lingkungan hidup di luar pengadilan, yakni melalui mediasi penal. ${ }^{5}$

Tidak dimungkinkannya penyelesaian perkara tindak pidana di luar pengadilan, terlihat lebih jelas di bidang hukum lingkungan hidup, di dalam UUPPLH secara tegas disebutkan bahwa penyelesaian perkara/sengketa

${ }^{4}$ Dibyo Widodo, dalam Syahrul Machmud, Penegakan Hukum Lingkungan Indonesia, (Bandung: Mandar Maju, 2007), halaman 190.

${ }^{5}$ Mediasi penal pada hakikatnya adalah sebuah mekanisme penyelesaian perkara tindak pidana melalui forum perundingan antara pelaku dan korban tindak pidana dengan dibantu seorang Mediator Penal, untuk membuat kesepakatan yang bersifat win-win solution. 
lingkungan hidup di luar pengadilan tidak berlaku terhadap tindak pidana lingkungan hidup. ${ }^{6}$

Dengan melihat kondisi penegakan hukum pidana terhadap perbuatan pencemaran dan/atau perusakan lingkungan hidup yang terlah berlangsung selama ini, sudah seyogyanya mediasi penal dijadikan alternatif penyelesaian perkara tindak pidana lingkungan hidup di luar pengadilan. Menjadikan mediasi penal sebagai alternatif penyelesaian perkara tindak pidana lingkungan hidup selain bermanfaat bagi lingkungan hidup, sejalan dengan perkembangan hukum dalam tataran global, sejalan pula dengan hukum yang hidup dan berkembang dalam tataran lokal, yakni masyarakat adat di Indonesia yang telah memiliki mekanisme penyelesaian perkara melalui perundingan atau permusyawarahan untuk mencapai kesepakatan.

Posisi korban TPLH seperti halnya juga posisi korban tindak pidana pada umumnya sangat lemah. Dalam setiap tahapan dalam proses peradilan pidana, korban tidak terlibat langsung dalam memperjuangkan haknya. Posisi korban TPLH yakni lingkungan hidup sendiri, hampir-hampir terlupakan, karena pada umumnya korban dari konflik lingkungan hidup yang menjadi perhatian hanya individu atau sekelompok individu. Dalam konteks memperkuat posisi korban TPLH tersebut, penerapan mediasi penal sebagai penyelesaian perkara TPLH menjadi sangat relevan.

Konstruksi mediasi penal dalam penyelesaian perkara tindak pidana lingkungan hidup yang ideal di dalam sistem hukum pidana di Indonesia sudah saatnya disusun. Kebutuhan untuk menyusun dan menata mediasi penal dalam sistem hukum pidana di Indonesia bukan saja untuk memperbaiki mekanisme perlindungan dan pengelolaan lingkungan hidup dengan menggunakan sarana hukum pidana, tetapi yang terutama adalah sebagai upaya memperbaiki sistem hukum pidana dalam mengantisipasi perkembangan masyarakat yang semakin pesat.

\footnotetext{
${ }^{6}$ Pasal 85 ayat (2) UUPPLH: "penyelesaian sengketa di luar pengadilan tidak berlaku terhadap tindak pidana lingkungan hidup sebagaimana diatur dalam Undang-undang ini”
} 
Ketentuan yang tercantum dalam Pasal 85 ayat (2) UUPPLH menyatakan bahwa, penyelesaian sengketa di luar pengadilan tidak berlaku terhadap tindak pidana lingkungan hidup sebagaimana yang diatur dalam undangundang tersebut. Rumusan Pasal 85 ayat (2) UUPPLH ini sangat jelas menutup kemungkinan dilakukannya mediasi penal dalam penyelesaian perkara TPLH.

Pembaruan substasi hukum pidana dalam rangka memberikan tempat kepada mediasi penal sebagai alternatif penyelesaian TPLH di luar pengadilan, dapat dimulai dengan memberikan dasar hukum dari mediasi penal. Untuk memberikan dasar hukum dimaksud, maka diperlukan perubahan atau revisi terhadap peraturan perundang-undangan yang berkaitan dengan pengaturan tentang proses penyelesaian perkara tindak pidana. Sebagaimana yang telah dikemukakan sebelumnya, sampai saat ini belum terdapat pengaturan tentang proses penyelesaian perkara tindak pidana melalui mediasi penal. Sehingga pembaruan di sini lebih bermakna sebagai penambahan suatu lembaga baru, yakni mediasi penal ke dalam sistem hukum pidana di Indonesia.

Berkaitan dengan hal di atas, rumusan Pasal 85 ayat (2) UUPPLH seyogyanya direvisi untuk memberi dasar hukum bagi penyelesaian TPLH di luar pengadilan. Rumusan bisa secara tegas menyebutkan bahwa penyelesaian TPLH dapat diselesaikan melalui lembaga di luar pengadilan; atau rumusan yang tidak membatasi perkara lingkungan hidup yang bisa diselesaiakan melalui lembaga di luar pengadilan. Jadi, rumusan yang tertuang dalam Pasal 85 (2) UUPPLH dapat berbunyi: "Penyelesaian perkara di luar pengadilan berlaku terhadap perkara perdata dan perkara tindak pidana lingkungan hidup sebagaimana diatur dalam Undang- Undang ini”. Atau: ayat (2) dari Pasal 85 dihapuskan.

Di dalam Peraturan Pemerintah yang mengatur tentang penyelesaian sengketa di luar pengadilan seyogyanya ditambahkan juga beberapa ketentuan yang mengatur tentang penyelesaian perkara TPLH melalui mediasi penal. Pengaturan tersebut meliputi syarat-syarat, prosedur, jangka waktu, lembaga penyelenggara dan hal-hal lainnya yang diperlukan dalam 
penyelenggaraan penyelesaian perkara TPLH melalui mediasi penal.

Melalui proses mediasi penal, korban TPLH berperan sebagai subyek yang berperan aktif dan otonom. Proses mediasi penal yang mengutamakan perundingan antara pelaku dan korban TPLH untuk menyelesaikan sendiri konflik yang terjadi di antara mereka bernilai positif. Nilai positif bagi korban yang terutama adalah karena dalam proses mediasi penal, korban memiliki kesempatan yang luas untuk memaparkan kerugian dan penderitaan yang dialaminya akibat TPLH yang dilakukan oleh pelaku. Korban juga memiliki kesempatan untuk memahami kondisi pelaku TPLH, selanjutnya korban dapat mengungkapkan harapan maupun keinginannya.

Mediasi penal yang mengutamakan proses yang berorientasi pada dialog dengan penekanan pada kebutuhan si korban dan keadaan pelaku untuk dimintai pertanggungjawaban, dapat menghasilkan perjanjian ganti kerugian yang dapat memenuhi harapan korban. Di samping itu, yang sangat penting juga adalah, proses dialog dapat memenuhi kebutuhan emosional dan informasional dari si korban dan perkembangan dari empati si pelaku terhadap korban. Hal tersebut dapat membantu mencegah TPLH di masa mendatang. Dalam keadaan tertentu, perjanjian ganti rugi (restitution agreement) tidak menjadi hal terpenting bagi korban TPLH, ketika dibandingkan dengan kesempatan untuk menunjukkan perasaaan mereka langsung kepada pelaku TPLH mengenai segala perasaan dan penderitaan akibat tindakan yang telah dilakukan pelaku. Hal tersebut menunjukkan bahwa, proses penyelesaian perkara TPLH melalui mediasi penal dapat menyentuh aspek-aspek manusiawi dari pelaku dan korban TPLH.

\section{PENUTUP}

\section{a. Simpulan}

Latar belakang pemikiran perlunya alternatif penyelesaian perkara tindak pidana lingkungan hidup di luar pengadilan, yakni melalui mediasi penal adalah merupakan bentuk alternatif perlindungan hukum pidana pada korban Tindak Pidana Lingkungan Hidup. Hal ini berarti dalam perspektif pembaruan hukum 
pidana perlu dilakukan revisi yang berkaitan dengan perumusan Pasal 85 ayat (2) dimaksud seyogyanya juga dapat memberi dasar hukum bagi penyelesaian TPLH di luar pengadilan.

\section{b. Saran}

Perlu dilakukan revisi yang berkaitan dengan perumusan Pasal 85 ayat (2) UU No. 32 Tahun 2009, dengan tujuan dapat memberi dasar hukum bagi penyelesaian TPLH di luar pengadilan. Rumusan bisa secara tegas menyebutkan bahwa penyelesaian TPLH dapat diselesaikan melalui lembaga di luar pengadilan; atau rumusan yang tidak membatasi perkara lingkungan hidup yang bisa diselesaiakan melalui lembaga di luar pengadilan. Jadi, rumusan yang tertuang dalam Pasal 85 (2) UUPPLH dapat berbunyi: "Penyelesaian perkara di luar pengadilan berlaku terhadap perkara perdata dan perkara tindak pidana lingkungan hidup sebagaimana diatur dalam undang-undang ini”, atau: ayat (2) dari Pasal 85 dihapuskan.

\section{DAFTAR PUSTAKA}

\section{a. Buku-buku:}

Amirin, Tatang A. 1986. Menyusun Rencana Penelitian. Jakarta: CV. Rajawali.

Arief, Barda Nawawi. 2002. Bunga Rampai Kebijakan Hukum Pidana. Bandung: PT. Citra Aditya Bakti.

Kejahatan. Cet ke-3. Jakarta: Kencana,

Jaya, Nyoman Serikat Putra. 2005. Kapita Selekta Hukum Pidana. Semarang: Badan Penerbit Universitas Diponegoro.

Mikles, Matthrew B., dan A. Michael Huberman. 1992. Analisis Data Kualitatif. Terjemahan Tjetjep Rehendy Rohidi. Jakarta: UI Press.

Machmud, Syahrul. 2007. Penegakan Hukum Lingkungan Indonesia. Bandung: Mandar Maju. 
Muladi. 1997. Hak Asasi Manusia, Politik dan Sistem Peradilan Pidana. Semarang: Badan Penerbit Universitas Diponegoro.

----------. 1995. Kapita Selekta Sistem Peradilan Pidana. Semarang: Badan Penerbit Undip.

Sommers, M. 1992. Logika. Bandung,: Alumni.

Suriasumantri, Jujun S. 1996. Filsafat Ilmu-Sebuah Pengantar Populer. Jakarta: Pustaka Sinar Harapan.

Widnyana, I Made. 2007 .Alternatif Penyelesaian Sengekat (ADR). Jakarta: Indonesia Business Law Centre (IBLC).

\section{b. Peraturan Perundang-undangan:}

Sekretariat Negara RI. Undang-Undang No. 1 Tahun 1946 tentang Peraturan Hukum Pidana (KUHP). Jakarta, 1946.

Sekretariat Negara RI. Undang-Undang No. 8 Tahun 1981 tentang Hukum Acara Pidana (KUHAP). Jakarta, 1981.

Sekretariat Negara RI. Undang- Undang No. 32 Tahun 2009 tentang Perlindungan dan Pengelolaan Lingkungan Hidup. Jakarta, 2009. 
